\title{
CNBB, democracia e participação popular (1977-1989)
}

Alvaro de Oliveira Senra*

Resumo: O presente artigo busca analisar a documentação produzida pela Conferência Nacional dos Bispos do Brasil (CNBB) entre os anos de 1977 e 1989, tendo como recorte as proposições desta entidade sobre a democracia e a participação popular. A CNBB teve grande relevância política ao longo dos anos abordados, herdando do período do Regime Militar (1964-1985) o papel de articulador de extensos segmentos da sociedade civil. A análise da documentação produzida pela entidade, acompanhada de sua contextualização histórica e do debate com a bibliografia de referência utilizada, permitiu revelar a relação da CNBB com os pressupostos do catolicismo progressista.

Palavras-chave: CNBB. Igreja Católica. Democracia. Participação popular.

\section{Introdução}

As grandes manifestações de 2013 e o conturbado processo eleitoral de 2014 resultaram em uma crise política de dimensões inéditas, culminando na queda da presidente Dilma Rousseff (2016) e na ascensão de Michel Temer; a continuidade dessa crise e o quadro atual de instabilidade política e institucional em muito têm enfraquecido a crença na democracia brasileira, conquistada a duras penas ao final do Regime Militar (1964-1985). No momento de escrita deste artigo, a evidente fragilidade e a pouca credibilidade dos partidos, a polarização política, a combinação entre as crises

"Doutor em Ciências Sociais pela Universidade do Estado do Rio de Janeiro (UERJ). Professor do Centro Federal de Educação Tecnológica Celso Suckow da Fonseca (CEFET-RJ). E-mail: alvarosenra@gmail.com 
política e econômica, o papel desempenhado pela mídia e o poder superlativo do Judiciário evidenciam problemas de difícil solução e justificam o pessimismo de grande parte da população com os mecanismos democráticos, construídos três décadas atrás.

Desde os anos finais da década de 1970, o país vivia um quadro de profunda crise econômica, à qual se somava a "dívida social" acumulada durante os anos do Regime Militar: inflação alta, forte endividamento externo, baixas taxas de crescimento, desemprego, periferias urbanas inchadas e sem serviços essenciais, explosão da violência. Mas a perspectiva de retorno à democracia trazia ventos de esperança, permitia antever um futuro melhor e mobilizava amplos setores da vida política e da sociedade civil.

Entre esses setores, encontrava-se a Igreja Católica. O artigo aqui apresentado se propõe a abordar e analisar as proposições sobre democracia e participação popular formuladas pela Conferência Nacional dos Bispos do Brasil (CNBB), no processo de intervenção política que esta entidade fez no período de crise do Regime Militar e de retorno às liberdades democráticas.

$\mathrm{Na}$ passagem entre as décadas de 1970 e 1980, a CNBB se pronunciou a favor da democracia em dois importantes documentos: o primeiro se denominou Exigências cristãs de uma ordem política (CNBB, 1981a), aprovado pela XV Assembléia Geral da CNBB, em 1977; ele condensou os conteúdos das principais propostas utilizadas pela entidade até o fim do Regime Militar, em 1985. O segundo documento produzido pela CNBB naquele período e aqui utilizado é intitulado Reflexão cristã sobre a conjuntura política (CNBB, 1981b).

A partir de meados da década de 1980, coincidindo com a conclusão da transição para o regime democrático e com a previsível perspectiva de que iria se abrir um período de lutas envolvendo a organização política, econômica e social do país, a CNBB procurou estruturar, no conteúdo e na forma de atuação, suas contribuições fundamentais para essa nova organização. Naquele momento, suas propostas foram dirigidas principalmente para o processo constituinte, e podem ser encontradas nos seguintes documentos: Por uma nova ordem constitucional (CNBB, 1986a), Pronunciamentos da CNBB: coletânea 85/86 (CNBB, 1986b), Leigos e participação 
na Igreja (CNBB, 1986c) e Exigências éticas da ordem democrática (1989), este último posterior à promulgação da Constituição de 1988. Os documentos citados neste parágrafo e no anterior constituem as fontes de pesquisa para este artigo.

Como subsídio para as propostas adotadas pela CNBB também se utilizaram reflexões de documentos produzidos pela Conferência Episcopal Latino-Americana (CELAM), de grande repercussão no período temporal aqui abordado: A Igreja na atual transformação da América Latina à luz do Concílio (1969) e Evangelização no presente e no futuro da América Latina (1986).

Durante o período temporal aqui abordado a CNBB foi presidida por Ivo Lorscheiter (1979-1986) e Luciano Mendes de Almeida (1987-1995). A eleição deste último

interrompeu um ciclo de 15 anos em que se sucederam no cargo representantes de setores mais progressistas da Igreja. [...] Mesmo assim, sua eleição - que contou com o apoio das bases da Igreja e com o voto de figuras preeminentes do clero progressista, como dom Pedro Casaldáliga - foi considerada uma vitória sobre os segmentos conservadores da Igreja, que escolheram como candidato o arcebispo de Belo Horizonte, dom Serafim Fernandes de Araújo. (KORNIS; MONTALVÃO, 2001, p. 1532)

A CNBB foi fundada em 1952, sob o contexto democrático que se estendeu de 1945 a 1964. Ela pode ser entendida como uma reorganização política da Igreja Católica, diante de um quadro de modernização econômica, urbanização, diversificação social e religiosa que já não garantia mais sua hegemonia sobre a vida social brasileira, como havia ocorrido em períodos históricos anteriores. Ressalta-se que a criação da CNBB não foi um fato isolado; outras organizações nacionais, fundadas à mesma época, reuniram as ordens religiosas (a Confederação dos Religiosos do Brasil - CRB), as escolas católicas (a Associação de Educação Católica - AEC) e diversos movimentos leigos se formaram ou renovaram, a exemplo da Juventude Universitária Católica (JUC) e da Juventude Operária Católica (JOC). 
Esse processo de reorganização política do catolicismo não se restringiu ao Brasil, alcançando outras regiões do mundo ocidental no contexto de fortalecimento da democracia que se seguiu à derrota das potências nazifascistas, em 1945. Em vários países, foram inclusive criados ou recriados Partidos Democrata-Cristãos (PDCs), defensores das propostas sociais e políticas do catolicismo em regimes de democracia eleitoral. Vários tiveram e ainda continuam a ter influência. No Brasil, o PDC, fundado em 1948, não conseguiu a adesão substancial do clero nem se enraizou socialmente (DELLA CAVA, 1975, p. 32-33).

Um dado assume grande relevância e justifica o processo de reorganização do catolicismo institucional no Brasil: a porcentagem de católicos na população total do país declinou de 95,2\%, em 1940, para 93,1\% em 1960, 89,2\% em 1980, caindo a 73,8\% no ano 2000 . Por sua vez, os protestantes (evangélicos), principal segmento nãocatólico da população, apresentaram crescimento constante ao longo de toda a segunda metade do século XX, partindo de 2,6\% em 1940 e alcançando o patamar de $15,4 \%$ da população no ano 2000 , com um total de 26.000 .000 de adeptos, resultando em impacto para a correlação de forças na política brasileira. Os cidadãos praticantes de outros credos ou sem-religião, que somavam apenas 2,1\% em 1940, atingiram no ano 2000 a 10,8\% da população (PIERUCCI, 2004, p. 23; SANTOS, 2005, p. 180).

O censo feito pelo Instituto Brasileiro de Geografia e Estatística (IBGE) em 2010 detectou a diminuição do número de católicos para $64,6 \%$ da população; os evangélicos cresceram para $22,2 \%$, confirmando a tendência anteriormente verificada. Neste último censo, destacou-se, também, o aumento do contingente de brasileiros que se declararam sem religião, que totalizou $8 \%$ da população ${ }^{1}$.Esse processo de mudança da composição religiosa da população brasileira, e sua análise, podem ser resumidos por Antonio F. Pierucci: "Desde o começo, e isso remonta aos anos de 1950, a sociologia da religião praticada no Brasil foi sempre uma sociologia do catolicismo em declínio" (PIERUCCI, 2004, p. 25).

Desde sua criação, em meados do século XX, a CNBB tem sido a principal expressão política do catolicismo institucional no Brasil, além de ser o espaço onde se dão os embates e os compromissos 
entre as frações existentes no interior da Igreja Católica e se articula a síntese entre os princípios do catolicismo, seus interesses corporativos e seu posicionamento em relação a outras correntes (religiosas ou não) atuantes na sociedade. Tendo como método a análise da documentação produzida pela CNBB no período temporal contido neste artigo, relacionando-a ao contexto histórico e discutindo-a a partir do diálogo com a bibliografia secundária, pode ser observada a materialização escrita das demandas e das visões de mundo de uma instituição de natureza religiosa, que busca intervir na realidade através da ação política concreta.

\section{A CNBB, a democracia e a participação popular}

As transformações ocorridas durante os governos militares foram fundamentais para que se possa entender a concepção de democracia que a CNBB defenderia a partir da crise do Regime Militar. A CNBB havia apoiado, num primeiro momento, a deposição do presidente João Goulart. Dois meses após o golpe, a entidade publicou o documento intitulado Declaração da CNBB sobre a situação nacional, no qual justificava a derrubada do governo constitucional como uma ação preventiva contra a marcha do comunismo em direção ao poder (MAINWARING, 1989, p. 102).

No entanto, nos anos posteriores a 1964, houve episódios de repressão a inúmeros elementos vinculados ao catolicismo, como sindicalistas rurais, ativistas do Movimento de Educação de Base (MEB) e membros da hierarquia. Por sua vez, o caráter extremamente rápido e violento das transformações promovidas pelos militares, sobretudo no campo, as migrações e a miséria urbana decorrentes do modelo econômico concentracionista, que atingiram as bases sociais do catolicismo, além do próprio esvaziamento da sociedade civil, decorrente da repressão, levaram a Igreja Católica a gradualmente ampliar suas preocupações sociais e a ocupar o espaço que, em condições democráticas, seria área de atuação de outros atores políticos.

Situações e experiências vividas pelos católicos no Brasil e em outros países da América Latina confluíram para a II Conferência 
Geral do Episcopado Latino-Americano (CELAM), em Medellín, Colômbia, em 1968. Esta representou um marco extremamente importante para a história da atuação política da Igreja Católica nos países desta região. Para a II CELAM, contribuíram as concepções modernizantes e reformistas oriundas do Concílio Vaticano II (1962-1965), que propugnavam por uma intervenção mais ativa dos católicos na vida política e social, assim como toda uma série de práticas adotadas por setores do catolicismo ao longo das décadas de 1950 e 1960, das quais podem ser tomadas como exemplos a atuação das diversas frentes da Juventude Católica, o MEB e os sindicatos rurais católicos do nordeste brasileiro.

O texto produzido em Medellín caracterizava a situação social latino-americana como profundamente injusta, e propunha a luta pela justiça social como prioritária para a Igreja Católica, levando-a a apoiar a participação popular através da criação de "estruturas intermediárias" entre o Estado e os indivíduos, capazes de promover a participação política e a capacidade social de reivindicar soluções para os problemas existentes:

achamos que as comunidades nacionais devem ter uma organização global. Nela toda a população, especialmente as classes populares, deve ter, através de estruturas territoriais e funcionais, uma participação receptiva e ativa, criadora e decisiva, na construção de uma sociedade. Essas estruturas, intermédias, entre a pessoa e o Estado, devem ser organizadas livremente, em vista de seu desenvolvimento e participação concreta na realização do bem comum total. Constituem a trama vital da sociedade. São também a expressão real da liberdade e solidariedade dos cidadãos. (CELAM, 1969, p. 43-44)

Nos anos seguintes à Conferência de Medellín, de forma concomitante ao fortalecimento dos setores identificados com as resoluções "progressistas" do II CELAM no interior da hierarquia, a Igreja Católica converteu-se em centro da sociedade civil. Para esta condição contribuíram os obstáculos criados pelos governos militares à constituição de espaços "normais" de expressão dos movimentos sociais e das diversas correntes político-ideológicas existentes. 
A atuação política e as propostas adotadas pela Igreja Católica durante aqueles anos, no entanto, não devem ser vistas como resultado de um posicionamento unânime do conjunto da hierarquia e de suas entidades representativas: houve conflitos e resistências às transformações e sempre existiu um forte núcleo de reação conservadora que envolveu, inclusive, a rejeição a muitas das propostas adotadas em Medellín (MAINWARING, 1989, p. 271).

No Brasil, a adesão às ideias progressistas difundidas pela Conferência de Medellín agravou os conflitos internos da Igreja Católica, na medida em que ambos buscavam influenciar as decisões da hierarquia. A partir de 1970, no entanto, os setores progressistas passaram a ter maior influência nas decisões da CNBB, o que resultou em maior crítica da entidade ao Regime Militar e em maior apoio às pastorais e grupos voltados à organização popular (KORNIS; MONTALVÃO, 2001, p. 1529).

O início do pontificado de João Paulo II, em 1978, teve peso na retração das ideias que haviam se espalhado desde a II CELAM. O novo papa buscou enfraquecer os membros do clero identificados com as correntes progressistas, desestimulou a participação política e fortaleceu a disciplina hierárquica da Igreja Católica. Na passagem entre as décadas de 1970 e 1980, a contenção das políticas propostas em Medellín encontraria respaldo na III CELAM, realizada em 1979 na cidade de Puebla, no México. Embora mantivesse a linha de denúncias das injustiças que marcam a vida das sociedades latino-americanas, há um nítido esforço em reordenar a Igreja Católica na direção de seu "papel espiritual”, isto é, de uma maior delimitação de suas funções dentro de um espaço mais tradicional. A título de exemplo, o enquadramento das Comunidades Eclesiais de Base (CEBs), que tiveram enorme expansão posteriormente a Medellín, e que passaram a ser submetidas a um maior controle por parte da hierarquia:

a Igreja como povo histórico institucional representa a estrutura mais ampla, universal e definida, dentro das qual se devem inscrever vitalmente as CEBs, para não correrem o risco de degenerarem em anarquia organizativa, por um lado, ou elitismo fechado e sectário, por outro. (CELAM, 1986, p. 147)

Anos 90, Porto Alegre, v. 24, n. 46, p. 97-120, dez. 2017 
Apesar desse movimento de contenção, o peso do catolicismo progressista daria a tônica das ações da $\mathrm{CNBB}$ naquele período:

\begin{abstract}
Na década de 70, a Igreja Católica brasileira mostrou-se a mais progressista de toda a América Latina. Foi aqui que as CEBs se tornaram modelo para a Igreja dos países do terceiro mundo. Aqui se formou, sob a tutela da Igreja, toda uma militância política de esquerda. (PRANDI; SOUZA, 1996, p. 62)
\end{abstract}

Portanto, a partir do pontificado de João Paulo II, uma "restauração conservadora" imposta pelo Vaticano foi, aos poucos, enfraquecendo os setores progressistas. No Brasil, esse efeito foi sendo sentido gradativamente, e teve como marco a eleição de D. Lucas Moreira Neves, um conservador, para a presidência da CNBB em 1994 (PRANDI; SOUZA, 1996, p. 73).

No Brasil, a importância assumida pela CNBB na década de 1970 e seus posicionamentos políticos levaram-na a muitos conflitos com os governos militares. Seu peso decorreu do fato de que a Igreja Católica tornou-se o núcleo articulador da sociedade civil no vácuo criado pela desorganização dos outros sujeitos políticos e pela sua capacidade de sustentar, ao mesmo tempo, a atuação dos movimentos sociais e a interlocução com o Estado.

Um exemplo representativo das posturas adotadas pela CNBB naquele período pode ser encontrado no documento Exigências cristãs de uma ordem política, aprovado pela XV Assembléia Geral da entidade, em fevereiro de 1977. Nele explicitaram-se as divergências entre a Igreja e o Estado militar. Para a CNBB,

a participação política é uma das formas mais nobres do compromisso a serviço dos outros e do bem comum. Ao contrário, a falta de educação política e a despolitização de um povo, e especialmente dos jovens, pela qual fossem reduzidos à condição de simples expectadores ou de atores de uma participação meramente simbólica, prepararia e consolidaria a alienação da liberdade do povo nas mãos da tecnocracia de um sistema. (CNBB, 1981a, p. 5) 
Ainda nas linhas do documento citado, criticou-se o uso constante de mecanismos repressivos por parte do Estado,

é dever do Estado respeitar, defender e promover os direitos das pessoas, das famílias e das instituições. Toda ação exercida sobre elas pelo Estado deve fundar-se no direito que deriva de sua responsabilidade pelo bem comum. (...) É nesse direito que se funda a força da autoridade. Toda força exercida à margem e fora do direito é violência. Um Estado de direito se caracteriza, pois, por uma situação jurídica estável, na qual as pessoas, as famílias e as instituições gozam de seus direitos, e têm possibilidades concretas e garantias jurídicas eficazes para defendê-los e reivindicá-los legalmente. (CNBB, 1981a, p. 9-10)

Diante de um Estado que adquiriu natureza tão superlativa a ponto de sufocar a sociedade civil, a CNBB defendeu a autonomia dos espaços societários e apoiou a criação de mecanismos de participação popular, numa ênfase que seria mantida ao longo da década de 1980. As críticas não se limitaram ao autoritarismo político, abarcando as prioridades econômicas adotadas pelo Regime Militar. Toma-se como exemplo o documento intitulado Reflexão cristã sobre a conjuntura política, que fez severas críticas às políticas econômicas adotadas pelos militares:

acentuou-se, nestes últimos anos, uma orientação da economia para prioridades favorecedoras das classes de altos rendimentos, inclusive mediante formas requintadas de corrupção e suborno, em direta oposição aos interesses do povo. Um modelo concentrador de rendas e estimulador de um consumismo sofisticado, em contraste com as carências básicas da população, levou-nos à situação de sermos hoje um dos países com mais alta taxa de desigualdade entre os grupos de maior e menor renda. (CNBB, 1981b, p. 7)

Em contrapartida a essa situação, o documento proclamou que deveria se buscar a democracia como saída; no entanto, esta 
não poderia se contida em um mero retorno aos procedimentos formais, avançando em direção a conteúdos sociais:

a democracia, hoje objeto de consenso nacional, em países como o Brasil, marcados por estas formas inaceitáveis de iniqüidade social, não consiste apenas na preservação das liberdades políticas. Consiste também num processo de incorporação das grandes massas a formas superiores de educação e de capacitação, a um nível melhor de vida e à plena participação nas decisões políticas. A democracia política é uma forma e um pré-requisito, cujo conteúdo e destinação é a democracia social. (CNBB, 1981b, p. 10).

No mesmo texto, a CNBB propunha, para a realização desses objetivos, a organização ampla da sociedade, além da criação de mecanismos de democracia direta:

para a democracia, não bastam eleições livres. É preciso ainda criar condições para que o povo se organize, seja pelo acesso à representação político-partidária, seja na expressão direta de seus anseios, pela criação de organismos comunitários, como associação de bairros, ou pelo recurso a formas plebiscitárias de manifestação da vontade do Povo. Só assim ele será capaz de dar respaldo aos que eleger e exigir deles o cumprimento dos compromissos assumidos. Somente um povo organizado nas mais variadas formas espontâneas e livres será capaz de ser sujeito de um processo racional e pacífico de vez que só organizado será capaz de reunir-se ostensivamente e discutir seus destinos de modo racional. (CNBB, 1981b, p. 12-13).

A documentação citada assume grande relevância, não somente pelo peso político de que dispunha a CNBB naquele momento; havia outra razão: em pleno processo de declínio do Regime Militar, outros atores políticos estavam se movimentando e ampliando sua atuação. A sociedade civil passava por uma diversificação e a CNBB se transformava em um sujeito a mais no jogo político, precisando mobilizar a sua área de influência social. 
Conforme Scott Mainwaring,

gradualmente, a redemocratização permitiu o renascimento da sociedade civil e, como resultado, a Igreja não mais se sentiu compelida a se manifestar pela sociedade civil como antes. Uma vez que outras instituições podiam cada vez mais assumir as funções políticas, alguns moderados da Igreja, que anteriormente haviam dado seu apoio ao envolvimento político mais profundo, agora favoreciam maior cautela. (MAINWARING, 1989, p. 272).

Essa retração da Igreja Católica às suas funções mais tradicionais não se deveu somente à reativação de outros segmentos da sociedade civil. Em seu interior, a centralização promovida por João Paulo II e a pressão da hierarquia fortaleceram os conservadores. Essa nova fase pode ser simbolizada pela condenação ao silêncio imposta em 1984 a Leonardo Boff, teólogo e importante representante dos setores vinculados à chamada "Teologia da Libertação". A reorganização em torno da hierarquia religiosa mais tradicional e o esvaziamento das CEBs também incluem-se entre as consequências do processo de reorganização então desencadeado pelo Vaticano. Houve, no entanto, protestos e resistência por parte de bispos, religiosos e leigos, e a tônica progressista continuaria a influenciar os documentos produzidos pela CNBB ao longo da década de 1980 .

A partir de 1982, o Regime Militar entrou em franco declínio. A vitória de candidaturas oposicionistas para os governos dos principais estados e a mobilização de uma ampla campanha popular, conhecida como "Diretas Já", que reuniu milhões de pessoas em comícios organizados em todo o país, aceleraram o processo de transição para a democracia.

O que caracterizou aquele momento foi uma combinação entre o enorme impulso democrático que vinha da sociedade civil, a grave crise econômica, as demandas sociais reprimidas que vinham à tona e os compromissos assumidos pela Aliança Democrática, que assumira o governo em 1985 pela via do Colégio Eleitoral, após a derrota da Emenda das "Diretas Já”. A transição para a democracia se completara sob hegemonia liberal, reunindo a oposição moderada organizada principalmente no Partido do Movimento Democrático 
Brasileiro (PMDB) e as dissidências do Regime Militar, reunidas no Partido da Frente Liberal (PFL). A chapa Tancredo Neves/José Sarney expressava essa hegemonia. Com o falecimento de Tancredo, José Sarney assumiria a presidência em 1985, conduzindo o processo de normalização da democracia, o que implicava a convocação de uma Constituinte.

A CNBB acompanhou e buscou influenciar o rumo dos embates políticos travados na discussão envolvendo a Constituinte. Nas linhas de Por uma nova ordem constitucional (documento elaborado pela XXIV Assembléia Geral da CNBB), se encontra a defesa dessa participação:

no processo constituinte, que permitirá consolidar os avanços dos últimos anos, a Igreja deve colaborar, como parte da sociedade, numa busca que será de todo o corpo social. Ela não pretende que a Constituição seja confessional. Numa linha de coerência com a sua atuação até agora, ela trabalha para que se incorporem à nova Constituição os mecanismos e instrumentos democráticos - alavancas de transformação social- que permitirão a participação na elaboração da nova Constituição. (CNBB, 1986a, p. 12).

O mesmo texto reforça a ideia de extensão da democracia para além de seus limites meramente políticos:

o momento político em que vivemos é de transição. Este não se limita, no entanto, à passagem do ordenamento institucional herdado do regime anterior ao reencontro da democracia política. Ele se inscreve num processo histórico mais denso e permanente de superação de uma sociedade elitista, que exclui dos benefícios do desenvolvimento grandes parcelas da população. Ao mesmo tempo, busca uma democracia também econômica e social que estenda a todos a condição de cidadão participante e co-responsável pela melhoria das condições coletivas da vida. (CNBB, 1986a, p. 5-6). 
A saída proposta pela CNBB para se completar a transição para a democracia era o controle social sobre o Estado, através da criação de mecanismos de participação política direta, atribuindo à sociedade a condição de sujeito da transformação social, "conquistando instrumentos de exercício de uma democracia que lhe permitam organizar e controlar a ação do Estado, colocando-o a seu serviço" (CNBB, 1986a, p. 6-7).

O Estado passaria a ser visto como uma instância subordinada à sociedade, tendo em vista o bem comum, cabendo à Constituição estabelecer as estruturas necessárias para que este controle se exerça (CNBB, 1986a, p. 33-34).

A Constituinte foi eleita sob condições extremamente favoráveis ao bloco liberal-conservador vinculado à Aliança Democrática, de sustentação do governo Sarney (1985-1990) - principalmente devido ao impacto político e eleitoral causado pela temporária estabilização econômica advinda da implantação do Plano Cruzado. Teve, também, caráter congressual (os deputados e senadores foram eleitos não somente para elaborar a nova Constituição, mas também cumpriram seus mandatos como parlamentares; além disso, 23 senadores eleitos em 1982, ainda sob o Regime Militar, tiveram assento garantido nos debates). No entanto, o impulso democrático e o mecanismo inovador das Emendas Populares possibilitaram a impressionante subscrição de 12.277 .423 cidadãos por via desse mecanismo (BRASIL, 1987).

Foi através das Emendas Populares que a CNBB e outras entidades católicas demonstraram sua capacidade de intervenção política de forma direta. Os documentos aqui citados fundamentaram essa mobilização, possuindo, portanto, relevância inegável, como alicerce para uma ação política de envergadura. As Emendas Populares diretamente apresentadas pela CNBB foram as da família, com 516.000 assinaturas; da liberdade religiosa, com 212.588 assinaturas; da ordem econômica, com 284.604 assinaturas; e da educação, com nada menos que 750.077 assinaturas. Além dessas, a CNBB apoiou as Emendas Populares apresentadas pelo Conselho Indigenista Missionário (CIMI), pelo Plenário Pró-Participação e pela Campanha Nacional da Reforma Agrária (CNBB, 1990, p. 22). 
Em 1989, estando a Constituição em vigor, era mais do que evidente que o retorno à democracia não correspondeu às expectativas que havia criado. A crise econômica persistia, e o jogo político era marcado pelo fisiologismo e pelas pressões dos grupos econômicos, impedindo ou dificultando a implantação efetiva dos direitos previstos pela Constituição de 1988. Naquele ano, a XXVII Assembléia Geral da CNBB produziu Exigências éticas da ordem democrática, fazendo duros reparos à incapacidade da jovem democracia brasileira em prover bem-estar aos seus cidadãos:

a qualidade de vida vai-se deteriorando cada vez mais em seus vários aspectos: a nutrição, a saúde, a educação, a habitação, o transporte, o saneamento básico. A mortalidade infantil nas áreas mais carentes infelizmente ainda é alta e desafia a consciência nacional. A situação dos menores abandonados que perambulam nas ruas não recebeu ainda adequado encaminhamento por parte da sociedade, apesar dos esforços recentes. Aumentaram os índices de evasão e de repetência escolar. O déficit habitacional, especialmente para as populações de baixa renda, atingiu níveis escandalosos, agravados pelas péssimas condições de saneamento e preservação ambiental. (CNBB, 1989, p. 18)

Diante de um quadro visto de forma muito negativa, a expectativa de fortalecimento da democracia se encontrava na sociedade civil. O texto da CNBB sugeriu, como possibilidade de aprofundamento da democracia,

o espírito de solidariedade de tantas comunidades de base, grupos e associações de bairro, movimentos de trabalhadores; espírito este que se afirma mesmo lá onde se desagrega a cultura tradicional, resistindo ao individualismo da modernidade; o crescente desejo de participação, em todos os níveis, que leva pessoas e grupos a sair da atitude de passividade e resignação, para assumir atitudes críticas, tomar iniciativas e promover a defesa de seus direitos; [...] o fortalecimento da organização e o dinamismo de movimentos populares 
e de associações de classe que, por sua autenticidade, se empenham em compreender, representar e promover as justas aspirações do povo. (CNBB, 1989, p. 29-30)

As referências à necessidade de espaços e instrumentos de participação no interior da democracia, contidas na documentação produzida pela CNBB a partir da segunda metade da década de 1970 apresentam uma linha de continuidade notável, e indicam uma concepção que ultrapassava a perspectiva liberal, que tende a delimitar a democracia no interior de mecanismos representativos formais. No entanto, não devem ser vistas como algo decorrente de uma conjuntura muito específica, ou de uma determinada correlação de forças no interior da estrutura da Igreja Católica. Elas se baseiam numa interpretação progressista do catolicismo que se fortaleceu num contexto ditatorial, onde Estado e sociedade civil eram concebidos como campos opostos.

As experiências promovidas pelo catolicismo progressista da década de 1970, como a participação popular descentralizada nas Comunidades Eclesiais de Base (CEBs), foram de grande importância para enraizar essa concepção, permitindo à Igreja Católica "ultrapassar o Estado na corrida rumo ao domínio das populações marginalizadas pelo processo econômico nacional, no campo e na cidade. Foi para isso que ela se muniu de instrumental técnico e humano neste período" (ROMANO, 1979, p. 191).

Embora os documentos que constituem a fonte de pesquisa deste artigo tenham referência num contexto histórico específico, estão em consonância com uma postura geral adotada pela Igreja Católica no mundo moderno, a saber: a defesa da autonomia da sociedade civil em relação ao Estado, através de dispositivos que garantam a liberdade de autodeterminação das organizações e instituições civis. Com o nascimento do Estado moderno, "a sociedade civil é o privilegiado campo de atuação para a realização de seu principal fundamento institucional: a promoção da 'transcendência da pessoa’ contra a racionalidade do Estado” (DOIMO, 1992, p. 296).

A defesa que a CNBB fez da sociedade civil e da participação popular como centros da democracia também pode ser abordada a partir de uma premissa: a necessidade de um espaço societário entre 
o Estado e o mercado, autônomo em relação aos polos estruturantes da vida moderna, o Estado como portador de uma racionalidade de fundo secularista, e o mercado como espaço do exercício da liberdade individual e das disputas próprias do mundo dos interesses. $\mathrm{O}$ primeiro definido como centro da vida pública, o segundo como local de realização do interesse privado.

A conceituação de sociedade civil revelada nos documentos da CNBB distingue-se daquela construída pelo pensamento liberal dos séculos XVIII e XIX, em que a sociedade civil difere do espaço estatal, sendo dotada de formas e princípios próprios. Seu conteúdo seria determinado, em grande parte, pelo papel desempenhado pela ação dos interesses individuais em meio à liberdade proporcionada pelo mercado. A racionalidade do mercado como espaço de realização dos interesses individuais, emancipados dos entraves criados pelo Estado, encontraria sua legitimidade ao promover a pacificação das relações sociais, impondo limites à ação arbitrária dos Estados (HIRSCHMANN, 2000, p. 95). Para além das fronteiras do liberalismo, a dicotomia entre mercado/sociedade civil e Estado manteve-se com Karl Marx, para quem a sociedade civil constituía "o domínio autônomo da propriedade privada e das relações de mercado" (KUMAR, 1996, p. 718).

No século XX, vertentes do pensamento marxista conceituaram a sociedade civil como a esfera onde a dominação de uma classe, fração de classe ou bloco de classes sobre o conjunto da sociedade é efetuada através da criação e reprodução de condições intelectuais e morais para o seu exercício ("hegemonia”), de forma complementar (e não oposta) à sociedade política (o Estado, entendido em sentido restrito), que reserva para si o papel de garantidor desta dominação por via da possibilidade de utilização de mecanismos coercitivos.

Antonio Gramsci denominou de "ocidentalização" a ampliação das condições gerais de sociabilidade política, levando o Estado a transbordar de suas funções mais definidamente repressivas e a abarcar um momento consensual, expresso nas políticas sociais. Sob estas condições, o exercício da vida política superou as fronteiras limitadas do Estado em senso restrito, expandindo-se em direção aos espaços amplos da sociedade civil, onde, sob as condições representadas pelas práticas sociais hegemônicas, a vida 
política implica a capacidade de mobilização, de negociação, de enfrentamento e conciliação entre os vários sujeitos que atuam nas inúmeras arenas formadas pela ampliação das funções estatais (GRAMSCI, 1988, p. 92).

Esta concepção nega a existência de espaços radicalmente diferenciados entre Estado (sociedade política) e sociedade civil. Ambos constituiriam dois momentos do Estado moderno em sua forma plenamente desenvolvida, capacitado tanto para a organização do convencimento do conjunto da população para a legitimidade das relações que garante, quanto para o possível uso da força para defendê-las.

As concepções apresentadas, de matriz liberal ou socialista, reforçam a ideia da bipolaridade estruturante da vida moderna, ao apresentar a sociedade civil como o terreno onde a racionalidade individual pode se realizar (o mercado), ou como resultado do processo de expansão da esfera estatal, anteriormente restrita às funções repressivas.

Esta bipolaridade aparece de outra forma, igualmente moderna: através da dicotomia entre público e privado. A afirmação gradativa dos Estados-nação significou, também, a crescente identificação destes como sinônimo de espaço público, tendente a expandir-se sobre o espaço privado em virtude da adoção de políticas sociais, de mecanismos de controle e regulação econômica e da submissão imposta a indivíduos e grupos infra-estatais, invertendo, inclusive, o processo inicial que resultou nas revoluções liberais. O sentido de "privado", por sua vez, transformou-se cada vez mais em sinônimo de lugar onde agem os interesses econômicos (BOBBIO, 1987, p. 25).

Diante dessa dicotomia, qual seria o papel de instituições não vinculadas ao mercado e que se distanciaram do Estado, como é o caso da Igreja Católica? Leigos e participação na Igreja, publicado em 1986, indicou respostas a essa questão:

A Igreja sai da órbita do Estado para a sociedade civil. Deve-se dizer que isso não acontece assim porque a Igreja quer, mas por força da própria natureza secular e autônoma dos Estados modernos. Eles não precisam da legitimação religiosa e da fundamentação "teológica" que, por acaso, a 
Igreja lhes possa oferecer. Eles produzem sua própria ideologia legitimadora para justificar sua existência e o próprio exercício do poder do Estado. Daí a necessidade de buscar um lugar ao sol para garantir um espaço na sociedade. (CNBB, 1986b, p. 22-23).

Em 1989, em resposta à incapacidade do Estado em atender às demandas sociais que afligiam a sociedade brasileira após duas décadas de governos militares, a XXVII Assembléia Geral da CNBB aprovou resolução intitulada Exigências éticas da ordem democrática, atribuindo as origens da crise à

separação que o mundo moderno criou entre ética e religião, de um lado, política e economia, de outro. A consciência moral parece restringir-se ao âmbito das questões individuais, à esfera íntima da pessoa. As decisões no campo econômico e político obedecem unicamente à lógica do lucro e do poder, escapando ao juízo ético. Esta separação pesa até hoje sobre a sociedade brasileira e pode explicar, em grande parte, o fato de que o Brasil, um dos maiores países católicos, está entre os que apresentam as maiores desigualdades sociais e a trágica ausência de ética cristã na organização sócio-econômica, nas instituições e costumes políticos. (CNBB, 1989, p. 31-32).

Portanto, a Igreja Católica se propõe desempenhar um papel de relevo na sociedade civil. Este não é fundamentado somente nos pressupostos originários de sua origem religiosa; na qualidade de uma instituição organizada, ela também promove ações capazes de materializar seus interesses e suas proposições. Essas ações, no entanto, são fundadas em uma lógica própria. Nas palavras de Roberto Romano,

certas análises da atividade pública da Igreja Católica passam ao largo de um aspecto necessário à compreensão de sua especificidade. Limitam-se ao reconhecimento das formações sociais, das estruturas econômicas e das organizações 
políticas em que sua atuação se desenrola, ignorando o sistema de representações com que ela própria apreende essas realidades e a linguagem com que as transfigura simbolicamente. Assim, deixa-se perder o significado da doutrina católica quando ativada pela Igreja como força instituinte de sua prática no plano espiritual e secular, de seu programa próprio de domínio social. (ROMANO, 1979, p. 19).

Essa atividade pública resulta em propostas que são apresentadas à sociedade e ao Estado, e se consubstanciam nas formas de atuação política privilegiadas pela Igreja Católica, em diferentes contextos históricos: ação das lideranças hierárquicas, movimentos de leigos católicos, partidos políticos, grupos de pressão, utilização dos meios de comunicação e criação de entidades de representação, como é o caso da CNBB.

Cabe, aqui, uma observação que diz respeito à extensão social e ao peso político das proposições adotadas pela CNBB. Conforme foi afirmado, não existiu no Brasil um partido apoiado oficialmente pela hierarquia católica, mas um conjunto de movimentos sociais e de parlamentares que tinha (e ainda tem) como referência as propostas adotadas pela CNBB.

Exemplifica-se com a sustentação dada pela CNBB e pelas pastorais católicas ao "novo sindicalismo" e aos movimentos comunitários, muito mobilizados no período de declínio do Regime Militar (1975-1985), e no apoio àquele que é, provavelmente, o mais visível movimento social do Brasil contemporâneo, o Movimento dos Trabalhadores Rurais Sem-Terra (MST). Da mesma forma, entidades católicas têm vínculo com grande número de Organizações não-Governamentais (ONGs), denominação que abrange inúmeras entidades de assessoria a movimentos populares, organismos assistenciais, de atuação temática mais específica (defesa da infância, apoio a populações de rua, promoção da cultura negra), atendendo a demandas que escapam à ação sistematizada do Estado. Pesquisa do Instituto Superior de Estudos da Religião (ISER), no início da década de 1990, detectou que 28,8\% das ONGs declararam possuir vínculos oficiais ou informais com a Igreja Católica; além disso, um percentual maior possui marcas que indicam atuação próxima 
aos espaços eclesiais, como origem de seus agentes, entidades de financiamento, movimentos junto aos quais desenvolvem seus trabalhos (DOIMO, 1992, p. 290).

A constatação dessa influência social, por si, expõe a relevância da documentação aqui abordada. Ao longo do período aqui estudado, a CNBB manteve um posicionamento crítico aos militares, à sua herança econômica e social e propôs incorporar mecanismos de participação popular à nascente democracia.

Ao término da década de 1980, um novo contexto histórico se iniciava. Se, ao final do Regime Militar, um Estado autoritário, incapaz de atender às necessidades da população e fechado à participação da sociedade era o centro da reflexão política da CNBB, após 1989 um novo projeto se tornava hegemônico, centrado na ideia do mercado como centro organizador da sociedade.

A CNBB foi crítica à implementação do projeto neoliberal no Brasil, incrementado com a vitória de Fernando Collor nas eleições presidenciais de 1989. Em 1992, o texto Das diretrizes a Santo Domingo, preparatório à participação da CNBB na IV Conferência Geral do Episcopado Latino-Americano (IV CELAM), denunciou que

os mecanismos de economia de mercado produziram no Terceiro Mundo (e também no Primeiro) massas excluídas dos benefícios do modelo de desenvolvimento adotado pelo sistema capitalista neoliberal, que tem sacrificado tantas vidas humanas." (CNBB, 1992, p. 23).

$\mathrm{Na}$ passagem entre as décadas de 1980 e 1990, a CNBB atualizou a concepção de sociedade civil como espaço autônomo em relação ao Estado e, ao mesmo tempo, ao mercado, diante de um novo contexto político caracterizado por políticas que privilegiam este último.

\section{Conclusão}

A produção documental da CNBB abordada neste artigo, assim como as diferentes áreas para onde a entidade dirigiu suas 
preocupações e sua atuação (desigualdades econômicas e sociais, reforma agrária, infância, família, educação) permitiriam analisar suas propostas a partir de diferentes ângulos. Por que, então, o recorte escolhido residiu nas proposições sobre democracia e participação popular?

Três décadas após a elaboração e divulgação dos documentos que foram aqui utilizados como fontes de pesquisa, a democracia brasileira vive uma crise profunda. No momento em que este artigo é escrito, há no Congresso Nacional propostas de retirada de direitos sociais que foram consagrados na Constituição Democrática de 1988, encontrando uma resistência social que, até o momento, está limitada a forças políticas organizadas. A reforma política está estagnada, e há poucas expectativas de mudanças até as eleições de 2018. O poder da mídia esvazia as discussões sobre modelos políticos e econômicos alternativos ao neoliberalismo. A democracia, no Brasil e em outros países, parece viver um momento de impasse e, talvez, de declínio.

A constatação desses graves problemas pode levar a uma idealização dos anos aqui abordados. De fato, o impulso democrático era imenso, após anos de represamento da liberdade de expressão e das demandas sociais, por parte dos governos militares. Mas as condições da vida brasileira de então reproduziam sua trajetória de profundas desigualdades econômicas, sociais, regionais e raciais, agravadas por um modelo econômico que favorecia os grandes grupos empresariais e pela crise econômica e inflacionária.

No entanto, o retorno à democracia acendia expectativas e mobilizava a sociedade. A CNBB teve então papel de destaque no contexto da sociedade civil, produzindo documentos que enfatizaram a defesa de uma democracia social, que fosse além das formalidades, e a participação do povo organizado nas decisões políticas. É fundamental destacar que a CNBB e outras entidades católicas não se limitaram a uma ação discursiva, mobilizando a população, apresentando Emendas Populares e pressionando os deputados constituintes.

Passados trinta anos do retorno à democracia política, chama a atenção, na crise atual, o papel discreto desempenhado pela CNBB, pelo menos até agora. Talvez essa discrição venha de seu peso 
político relativamente menor, consequência do declínio constante da extensão social do catolicismo.

Ao mesmo tempo, a Igreja Católica se tornou mais conservadora e preocupada em preservar seus espaços de influência tradicional, diante do imenso crescimento de outras denominações religiosas, notadamente evangélicas pentecostais. Movimentos de discurso fortemente despolitizado, como a Renovação Carismática Católica, atuante desde a década de 1960, foram apoiados pelo Vaticano a partir do final da década seguinte, atingindo milhões de seguidores no Brasil e esvaziando as formas de atuação estabelecidas pelo catolicismo progressista pós-Medellín, como as CEBs. Só muito recentemente, a partir do pontificado de Francisco, iniciado em 2013, parece haver uma contenção desse conservadorismo, mas esse movimento enfrenta resistências e, de qualquer forma, demanda um tempo para atingir as bases sociais da Igreja Católica.

Em suma, a crise atual parece ter na Igreja Católica, ou, mais especificamente, na CNBB, um ator de envolvimento mais tímido e de menor repercussão social do que no período abordado pelo recorte temporal deste artigo.

Mas, se pensarmos a saída para a crise política atual não através do recurso aos mecanismos autoritários, ou às formas de conciliação "pelo alto", ambos tão presentes na história brasileira, mas, em sentido contrário, pelo aprofundamento da democracia e pela criação de mecanismos de participação que permitam superar a concepção liberal ora hegemônica, a consulta aos documentos produzidos pelo principal organismo institucional do catolicismo no Brasil, a CNBB, assume grande relevância, apresentando um acúmulo de experiência que não merece ser esquecido e contendo propostas que conservam grande atualidade.

CNBB, DEMOCRACY AND POPULAR PARTICIPATION (1977-1989) Abstract: This paper aims to analyze the documentation produced by the Brazilian National Bishops' Conference (CNBB) between the years of 1977 and 1989, focusing the propositions about democracy and popular participation. The CNBB had large political relevance throughout the addressed years, inheriting from the Military Regime (1964-1985) the role of articulator of extensive segments of civil society. The documentation's analysis, accompanied by the historical 
contextualization and the debate with the academic production studied, allowed reveal the CNBB's relation with the assumptions of the progressive catholicism. Keywords: CNBB. Catholic Church. Democracy. Popular participation.

\section{Notas}

${ }^{1}$ Disponível em: <https://ww2.ibge.gov.br/home/estatistica/populacao/censo2010/ caracteristicas_religiao_deficiencia/default_caracteristicas_religiao_deficiencia. shtm>. Acesso em: 25 out. 2017.

\section{Referências}

BOBBIO, Norberto. Estado, governo, sociedade: por uma teoria geral da política. Rio de Janeiro: Paz e Terra, 1987.

BRASIL. Assembléia Nacional Constituinte. Comissão de Sistematização. Emendas Populares. v. I. Brasília, DF: Senado Federal, 1987.

CONFERÊNCIA EPISCOPAL LATINO-AMERICANA (CELAM). Evangelização no presente e no futuro da América Latina: conclusões da Conferência de Puebla. 7. ed. São Paulo: Paulinas, 1986.

- A Igreja na atual transformação da América Latina à luz do Concílio: conclusões da Conferência de Medellín. Petrópolis: Vozes, 1969.

CONFERÊNCIA NACIONAL DOS BISPOS DO BRASIL (CNBB). Das diretrizes a Santo Domingo. São Paulo: Paulinas, 1992.

. Participação popular e cidadania: a Igreja no processo constituinte. São Paulo: Paulinas, 1990.

. Exigências éticas da ordem democrática (XXVII Assembléia Geral da CNBB). São Paulo: Paulinas, 1989.

. Por uma nova ordem constitucional. (XXIV Assembléia Geral da CNBB). São Paulo: Paulinas, 1986a. 1986b.

. Pronunciamentos da CNBB. Coletânea 1985/1986. São Paulo: Paulinas, . Leigos e participação na Igreja. São Paulo: Paulinas, 1986c.

. Exigências cristãs de uma ordem política (XV Assembléia Geral da CNBB). 9. ed. São Paulo: Paulinas, 1981a.

Anos 90, Porto Alegre, v. 24, n. 46, p. 97-120, dez. 2017 
CNBB, democracia e participação popular (1977-1989)

. Reflexão cristã sobre a conjuntura política. 3. ed. São Paulo: Paulinas, 1981b.

DOIMO, Ana M. Igreja e movimentos sociais pós-70 no Brasil. In: SANCHIS, P. (Org.). Catolicismo: cotidiano e movimentos. São Paulo: Loyola, 1992. p. 275-308.

GRAMSCI, Antonio. Maquiavel, a política e o Estado moderno. 6. ed. Rio de Janeiro: Civilização Brasileira, 1988.

HIRSCHMAN, Albert O. As paixões e os interesses: argumentos políticos para o capitalismo antes de seu triunfo. São Paulo: Paz e Terra, 2000.

KORNIS, Mônica; MONTALVÃO, Sérgio. Conferência Nacional dos Bispos do Brasil (CNBB). In: ABREU, Alzira A. et al. Dicionário histórico-bibliográfico brasileiro pós-1930. Rio de Janeiro: FGV; CPDOC, 2001. p. 1525-1534.

KUMAR, Krishan. Sociedade civil. In: BOTTOMORE, Tom; OUTHWAITE, William (Ed.). Dicionário do pensamento social do século XX. Rio de Janeiro: Zahar, 1996. p. 717-719.

MAINWARING, Scott. Igreja católica e política no Brasil (1916-1985). São Paulo: Brasiliense, 1989.

PIERUCCI, Antônio F. "Bye bye, Brasil”: o declínio das religiões tradicionais no Censo 2000. Estudos Avançados, São Paulo, v. 18, n. 52, p. 17-28, dez. 2004.

PRANDI, Reginaldo; SOUZA, André R. A carismática despolitização da Igreja Católica. In: PIERUCCI, Antônio F.; PRANDI, Reginaldo. A realidade social das religiões no Brasil: religião, sociedade e política. São Paulo: Hucitec, 1996. p. 59-91.

ROMANO, Roberto. Brasil, Igreja contra Estado: crítica ao populismo católico. São Paulo: Kairós, 1979.

SANTOS, Lyndon. O púlpito, a praça e o palanque: os evangélicos e o regime militar brasileiro. In: FREIXO, Adriano; MUNTEAL, Oswaldo (Org.). A ditadura em debate: Estado e sociedade nos anos do autoritarismo. Rio de Janeiro: Contraponto, 2005. p. 151-182.

Recebido em: 29/07/2017

Aprovado em: 10/10/2017 